\title{
SOIL ATTRIBUTES AND EDAPHIC NEMATOFAUNA IN PASTURES WITH PIG SLURRY SUCCESSIVE APLICATIONS ${ }^{1}$
}

\author{
DIEGO ARMANDO AMARO DA SILVA², DANNI MAISA DA SILVA²*, JANAÍNA TAUIL BERNARDO ${ }^{3}$, \\ CRISTIANO BELLÉ ${ }^{4}$, PAULO ROBERTO KUHN ${ }^{5}$, MASTRÂNGELLO ENÍVAR LANZANOVA ${ }^{2}$
}

\begin{abstract}
Considering that nematodes are quite sensitive to anthropic interventions, these organisms can be used as indicators of soil quality (SQ). The objective of this work was to study chemical and physical attributes and soil nematode as an indicator of soil quality in pasture areas with successive application of pig slurry (PS) in the Northwest of the state of Rio Grande do Sul. For this, the different areas were considered: Azevém + Tifton pasture with PS use for 14 years (A14), Azevém + Tifton pasture with use of PS for two years (A2) and native forest (NF), with a chemical and physical attributes nematofauna of the soil, with three replicates per treatment, in a randomized complete block design. The soil chemical attributes were sensitive to changes in pasture areas with successive application of PS, with increase in P content, compared to the NF area and soil OM content in the A14 area similar to that found in the NF area. In relation to the soil physical attributes, density and microporosity increased with the successive application of PS in ryegrass + tifton pasture areas, while macroporosity decreased, compared to NF areas. The nematodes of the Discocriconemella, Paratylenchus, Pratylenchus, Trichodorus, Tylenchus and free-living groups were efficient as indicators of soil quality, since they were able to evidence alterations in soil chemical and physical attributes between the ryegrass + tifton use of PS and in relation to the native forest.
\end{abstract}

Keywords: Bioindicators. Nematodes. Chemical quality. Physical quality.

\section{ATRIBUTOS DO SOLO E NEMATOFAUNA EDÁFICA EM PASTAGENS COM USO SUCESSIVO DE DEJETO LÍQUIDO DE SUÍNOS}

RESUMO - Considerando-se que os nematoides são bastante sensíveis às intervenções antrópicas, estes organismos podem ser utilizados como indicadores de qualidade do solo (QS). Neste trabalho objetivou-se estudar atributos químicos, físicos e a nematofauna edáfica como indicadora de qualidade do solo em áreas de pastagem com aplicação sucessiva de dejetos líquidos de suínos (DLS) no Noroeste do estado do Rio Grande do Sul. Para tal, foram consideradas as diferentes áreas: pastagem de Azevém + Tifton com uso de DLS há 14 anos (A14), pastagem de Azevém + Tifton com uso de DLS há dois anos (A2) e mata nativa (MN), sendo analisados atributos químicos, físicos e a nematofauna do solo, com três repetições por tratamento, em delineamento blocos casualizados. Os atributos químicos do solo foram sensíveis às mudanças em áreas de pastagem com aplicação sucessiva de DLS, com aumento no teor de P, em comparação com a área MN e teor de MO do solo na área A14 semelhante ao encontrado na área MN. Em relação aos atributos físicos do solo, densidade e microporosidade aumentam com a aplicação sucessiva de DLS em áreas de pastagem de azevém+tifton, enquanto que a macroporosidade diminuiu, em comparação com as áreas MN. Os nematoides dos grupos Discocriconemella, Paratylenchus, Pratylenchus, Trichodorus, Tylenchus e de vida livre são eficientes como indicadores da qualidade do solo, uma vez que evidenciam alterações nos atributos químicos e físicos do solo entre as áreas de pastagem de azevém+tifton com uso sucessivo de DLS e em relação à mata nativa.

Palavras-chave: Bioindicadores. Nematoides. Qualidade química. Qualidade física.

\footnotetext{
${ }^{*}$ Corresponding author

${ }^{1}$ Received for publication in $08 / 31 / 2018$; accepted in $08 / 28 / 2019$.

Paper extracted from the monograph of the Food Safety and Agroecology Specialization Course of the first author

${ }^{2}$ Unity Três Passos, Universidade Estadual do Rio Grande do Sul, Três Passos, RS, Brazil; damaro.agro@gmail.com - ORCID: 0000-00025671-8746, danni-silva@uergs.edu.br-ORCID: 0000-0002-3600-0462, mastrangello-lanzanova@uergs.edu.br-ORCID: 0000-0003-2285 -1052 .

${ }^{3}$ Unity Cachoeira do Sul, Universidade Estadual do Rio Grande do Sul, Cachoeira do Sul, RS, Brazil; janaina-bernardo@uergs.edu.br ORCID: 0000-0002-2461-5910.

${ }^{4}$ Soil Departament, Universidade Federal de Santa Maria, Santa Maria, RS, Brazil; crbelle@gmail.com - ORCID: 0000-0003-2247-3207.

${ }^{5}$ Empresa de Pesquisa Agropecuária e Extensão Rural de Santa Catarina, Mondaí, SC, Brazil; paulokuhn@epagri.sc.gov.br - ORCID: 0000 $-0002-6920-041 X$.
} 


\section{INTRODUCTION}

In recent years, concern about soil quality (SQ) has grown, since intensive use and mobilization can reduce its ability to maintain a sustainable biological production (CARVALHO et al., 2004; FREITAS et al., 2012). In this sense, the intensive and inadequate use of rural environments makes it necessary to know the processes responsible for the correct management of the soil, being essential to obtain sustainable agricultural production systems (SILVA et al., 2015).

In studies involving the relationship between agriculture and the environment, there is a growing need to adopt criteria that can evaluate current conditions as well as the ideals of agro-ecosystem compartments (MORAIS et al., 2015), and environmental indicators provide useful information for monitoring management practices (PEREIRA et al., 2007) and soil use.

Among the environmental indicators are the chemical (MORAIS et al., 2015), the physical (CARVALHO et al., 2004) and the biological (SILVA et al., 2015; SILVA et al., 2016), and the quality of these attributes provide adequate conditions for plant growth and development and for maintaining the diversity of soil-dwelling organisms (SANTOS et al., 2008). However, any modification in the soil can directly change its structure and biological activity and, consequently, its fertility, with effects on environmental quality and crop yield (GOMILDE et al., 2011).

In pig producing regions, the disposal of pig slurry (PS) is a serious environmental problem (BERWANGER et al., 2008), but if well managed, it can serve as an important alternative to pasture fertilization (SILVA et al., 2016) and positively influence the chemical (SCHERER et al., 2010), physical (RESENDE et al., 2012) and biological characteristics of the soil (SILVA et al., 2014; SILVA et al., 2016), acting on the edaphic quality as a whole. In this regard, in addition to soil physical and chemical indicators, the abundance and diversity of edaphic organisms, including nematodes, have been used as important indicators of soil quality (SANTORUFO et al., 2012). In this sense, the identification of individuals in each functional group allows advances in the understanding of processes arising from the edaphic and cultural management, and in the resilience of the ecosystem (RITZINGER et al., 2010). These organisms are sensitive to changes in the environment, as studies show that nematodes present in a community are more or less diversified according to the degree of anthropization of the environment in question, and that the activity and diversity of these organisms is also influenced by fluctuations in soil physicochemical characteristics (HOCEINI et al., 2017).

On the other hand, forest soils, which have not yet had anthropic disturbances, present a higher natural fertility than agricultural areas, which may be lost due to the transition to agriculture (ROVEDDER et al., 2013), so that, in the evaluation of sustainability, it is essential to monitor the physical, chemical and biological attributes of the soil (SILVA et al., 2015), considering as a quality parameter the areas with native forest.

Thus, the objective of this work was to study the chemical and physical attributes of the soil and the edaphic nematofauna community as soil quality indicators in pasture areas with successive application of pig slurry in the northwest of the state of Rio Grande do Sul.

\section{MATERIALS AND METHODS}

The study was carried out in a rural property $\left(27^{\circ} 30^{\prime} 44^{\prime \prime} \mathrm{S} ; 5^{\circ} 53^{\prime} 54^{\prime \prime} \mathrm{W}\right)$ in the municipality of Três Passos, in the northwest of the state of Rio Grande do Sul (RS). The regional soil is classified as Entisol (USDA Classification) with slope that varies from wavy to strongly wavy. The climate of the region is subtropical humid spring (ST PU) with average annual temperature of $18.1^{\circ} \mathrm{C}$, and average annual rainfall of $1.919 \mathrm{~mm}$ well distributed throughout the year (MALUF, 2000).

In the present study, three areas were considered as treatments: Ryegrass (Lolium multiflorum Lam.) Azevém+ Tifton (Cinodon spp. hybrid) pasture with successive use of pig slurry (PS) for 14 years (A14), Azevém + Tifton pasture (ryegrass + tifton) with successive use of PS for 2 years (A2), and native forest area (NF) as a comparison parameter of SQ. The PS presents, in the average density of $1020 \mathrm{~kg} \mathrm{~m}^{-3}$, according to the CQFS RS/SC (2016), the following characteristics: $3.91 \%$ of dry matter (DM); $3.44 \mathrm{kgm}^{-3}$ of $\mathrm{N} ; 2.99 \mathrm{~kg}$ $\mathrm{m}^{-3}$ of $\mathrm{P}_{2} \mathrm{O}_{5} ; 1.75 \mathrm{~kg} \mathrm{~m}^{-3} \mathrm{~K}_{2} \mathrm{O}$. The areas had 0.69 , 0.79 and 1.50 ha, respectively. Areas A2 and A14 received during the implantation of pastures, $2 \mathrm{Mg}$ $\mathrm{ha}^{-1}$ of limestone and were managed in a rotational grazing system with dairy cows, receiving annually about $200 \mathrm{~kg} \mathrm{ha}^{-1}$ year $^{-1}$ of urea and $200 \mathrm{~m}^{3} \mathrm{ha}^{-1}$ year ${ }^{1}$ of PS (SILVA et al., 2015).

The NF area used in the study is a fragment of the seasonal deciduous forest (IBGE, 2012) without environmental disturbance since the 1960s. The seasonal forests are the formations with the largest coverage area among the ones occurring in RS, prevailing in Upper Uruguay along the slopes of Serra Geral, predominating, especially in the case of this study, the red angico - Parapiptadenia rigida (Brenth.) Brenan, the canafístula - Peltophorum dubium (Spreng.) Taub., Timbaúva - Enterolobium contortisiliquum (Vell.) Morong and the Canjerana Cabralea canjerana (Vell.) Mart., emerging species that lose their leaves during the winter, characterizing the forest as seasonal (SCIPIONI et al., 2011). 
A randomized block design was used, with three replications of each treatment. For the determination of soil physical properties, three undisturbed soil samples were collected in each plot, in the depth from 0 to $0.10 \mathrm{~m}$, with the aid of volumetric steel rings, totaling nine replications per treatment. After collection, the samples were taken to the soil Physics Laboratory of the Federal University of Santa Maria (UFSM), where soil clay content (TEDESCO et al., 1995), Soil bulk density (Ds), were determined by the volumetric ring method, the Total porosity $(\mathrm{Pt})$, by the percentage of soil water saturation, in addition to Macroporosity (Mac) and Microporosity (Mic), determined in a "tension table" (TEIXEIRA et al., 2017). In the same soil sampling points for nematofauna analysis, three composite samples were collected, from $0-0.10 \mathrm{~m}$ depth, for analysis of the following chemical attributes: $\mathrm{pH}$ in water, calcium $(\mathrm{Ca})$, Magnesium $(\mathrm{Mg})$, potassium $(\mathrm{K})$, exchangeable aluminum $(\mathrm{Al})$, potential acidity $(\mathrm{H}+\mathrm{Al}), \mathrm{CTC}$ at $\mathrm{pH} 7$, effective CTC, base saturation, organic matter (OM), available phosphorus (P), and sulfur (S), according to the method described in Tedesco et al. (1995) and Teixeira et al. (2017).

For evaluation of the edaphic nematofauna, three composite samples (nine subsamples) per treatment were collected in each plot, totaling three replications per treatment, at a depth of $0-0.10 \mathrm{~m}$, being properly packaged and sent for extraction and identification. Each soil composite sample was divided into laboratory triplicate for analysis. Extractions were performed at the Phytopathology Laboratory of UFSM - Campus Frederico Westphalen. Subsequently, the soil samples were processed according to the method described by Jenkins (1964) to evaluate the occurrence and population density of the nematofauna under an optical microscope. Phytonematodes present in the soil were identified at gender level and quantified in number of specimens per $100 \mathrm{~cm}^{3}$ of soil per sample. The nematofauna was evaluated quantitatively through genera abundance, and qualitatively through species richness, relative frequency and Shannon Diversity Index $(\mathrm{H})$, Simpson Dominance Index (Is) and Pielou Uniformity Index $(\mathrm{J})$. The $\mathrm{H}$-index is defined as: $\mathrm{H}=$ $-\Sigma$ (pi log pi), where: pi $=$ ni $/ \mathrm{N}$; ni $=$ density of each group; $\mathrm{N}=$ total number of individuals in the group (MOÇO et al., 2005). The Is index is calculated by the following equation: Is $=\Sigma \mathrm{ni}(\mathrm{ni}-1) / \mathrm{N}(\mathrm{N}-1)$, where: $\mathrm{ni}=$ density of each order; $\mathrm{N}=$ total number of individuals in the group (URAMOTO et al., 2005). The $\mathrm{J}$ index is given by: $\mathrm{J}=\mathrm{H} / \log \mathrm{S}$, where: $\mathrm{H}=$ Shannon index; $\mathrm{S}=$ number of species or groups (MOÇO et al., 2005).

The present work particularly selected three of the most used, Shannon (H), Simpson (Is) and Pielou (J) Indices. The $\mathrm{H}$ index reflects the uncertainty of randomly catching an individual of the same species, ranging from 0 to 5 , the greater the diversity of organisms the higher the index (MOÇO et al., 2005). The Is index expresses the probability that two individuals from the same community belong to one species, ranging from 0 to 1 , and the higher the value, the greater the dominance of one group over the others (URAMOTO et al., 2005). In turn, $\mathrm{J}$ is treated as an equitability or uniformity index, where uniformity refers to the distribution pattern of individuals among species (MOÇO et al., 2005).

Nematode abundance data, soil chemical and physical attributes were subjected to analysis of variance (ANOVA) and means test (Tukey) at 5\% probability of error using the GENES program. In determining the richness and indices, determined using the DivEs 2.0 program, data from the treatment as a whole were used, and no averages were used. Additionally, Principal Component Analysis (PCA) was performed between the taxonomic groups of nematodes, soil chemical and physical attributes, and soil management systems in SPSS 19.0.

\section{RESULTS AND DISCUSSION}

The $\mathrm{pH}$ values were lower in areas A14 and A2 in relation to the NF area (Table 1), which was already expected, because due to the replacement of forest cover, there was degradation of organic matter (OM) and rapid mineralization, thereby acidifying the environment (ROVEDDER et al., 2013). In area $\mathrm{A} 2$, the $\mathrm{pH}$ values were higher than the A14 area, probably due to the application of limestone during implantation of the pasture, occurring only 2 years ago; in the A14 area, the $\mathrm{pH}$ values were lower than in other areas, although, according to Bison-Pinto et al. (2014), fertilization with PS tends to increase soil $\mathrm{pH}$. 
D. A. A. SILVA et al.

Table 1. Soil chemical attributes in the native forest area (NF), ryegrass + tifton pasture, using pig slurry for 14 years (A14) and 2 years (A2).

\begin{tabular}{|c|c|c|c|c|c|c|}
\hline \multirow{3}{*}{$\begin{array}{l}\text { Attributes }^{1} \\
\mathrm{pH} \text { (water) }\end{array}$} & \multicolumn{6}{|c|}{ Area } \\
\hline & \multicolumn{2}{|c|}{ NF } & \multicolumn{2}{|c|}{ A14 } & \multicolumn{2}{|c|}{ A2 } \\
\hline & 6.7 & $a^{*}$ & 5.5 & $\mathrm{c}$ & 5.9 & $\mathrm{~b}$ \\
\hline $\mathrm{Ca}\left(\mathrm{cmol}_{\mathrm{c}} \mathrm{dm}^{-3}\right)$ & 21.5 & $\mathrm{a}$ & 12.4 & $\mathrm{~b}$ & 11.0 & $\mathrm{~b}$ \\
\hline $\mathrm{Mg}\left(\mathrm{cmol}_{\mathrm{c}} \mathrm{dm}^{-3}\right)$ & 4.2 & ns & 5.1 & & 5.9 & \\
\hline $\mathrm{Al}\left(\mathrm{cmol}_{\mathrm{c}} \mathrm{dm}^{-3}\right)$ & 0.0 & $\mathrm{~ns}$ & 0.0 & & 0.0 & \\
\hline $\mathrm{H}+\mathrm{Al}\left(\mathrm{cmol}_{\mathrm{c}} \mathrm{dm}^{-3}\right)$ & 1.7 & $\mathrm{~b}$ & 5.0 & $\mathrm{a}$ & 3.1 & $a b$ \\
\hline $\mathrm{CTC}_{\mathrm{pH} 7}\left(\mathrm{cmol}_{\mathrm{c}} \mathrm{dm}^{-3}\right)$ & 28.3 & $\mathrm{~ns}$ & 22.5 & & 22.5 & \\
\hline $\begin{array}{l}\text { CTC effective }\left(\mathrm{cmol}_{\mathrm{c}}\right. \\
\left.\mathrm{dm}^{-3}\right)\end{array}$ & 26.6 & $\mathrm{a}$ & 17.5 & $\mathrm{~b}$ & 19.4 & $\mathrm{~b}$ \\
\hline Base Saturation (\%) & 93.7 & $\mathrm{a}$ & 77.9 & $\mathrm{c}$ & 86.1 & $\mathrm{~b}$ \\
\hline $\mathrm{OM}\left(\mathrm{g} \mathrm{kg}^{-1}\right)$ & 6.6 & a & 6.1 & a & 3.5 & $\mathrm{~b}$ \\
\hline$P\left(\mathrm{mg} \mathrm{dm}^{-1}\right)$ & 5.8 & $\mathrm{~b}$ & 66.9 & $\mathrm{a}$ & 45.9 & $\mathrm{a}$ \\
\hline $\mathrm{K}\left(\mathrm{mg} \mathrm{dm} \mathrm{m}^{-1}\right)$ & 339 & $\mathrm{~b}$ & 581 & $\mathrm{a}$ & 431 & $\mathrm{ab}$ \\
\hline $\mathrm{S}\left(\mathrm{mg} \mathrm{dm}^{1}\right)$ & 8.9 & $\mathrm{~b}$ & 14.3 & $\mathrm{a}$ & 10.5 & \\
\hline
\end{tabular}

${ }^{1} \mathrm{OM}=$ soil organic matter (Walkley-Black method). *Means followed by the same letter in the line do not differ from each other by Tukey's test $(\mathrm{p} \leq 0.05)$, and $\left({ }^{\mathrm{ns}}\right)$ not significant.

In the case of organic matter (OM), the NF area presented the highest content, not differing statistically from the A14, being explained by the higher carbon contribution by the plant biomass, provided by the natural vegetation (BISON-PINTO et al., 2014), which is stable but, when the soil is subjected to agricultural use, it can reduce sharply (SILVA JUNIOR et al., 2012), which partially explains the lower value in A2. However, the area with 14 years of successive use of PS (A14), presented higher OM than that of the area with only two years of use (A2), as reported by Scherer et al. (2010), with successive applications of PS over time, favoring increase in the soil OM content.

$\mathrm{Ca}$ and $\mathrm{Mg}$ contents were considered high in all treatments according to the Soil Chemistry and Fertility Commission (CQFS RS/SC, 2016). The Ca content was higher in NF, due to its low soil mobility (SILVA JUNIOR et al., 2012), similar to the $\mathrm{Mg}$ content, for which no differences were found between areas. In addition to the NF area presenting the highest $\mathrm{Ca}$ contents, it presented the highest effective CTC values, as well as higher base saturation (V), largely as a result of this nutrient, which contributes to the sum and saturation of bases in the soil.

The manure generated in swine farming can be used as a source of nutrients, such as N, P and $\mathrm{K}$ (CQFS RS/SC, 2016), with the application as soil fertilizer, being the main form of use of these organic residues (SILVA et al., 2015). In areas with PS, P levels were considerably higher than in NF, a fact also observed by Berwanger et al. (2008), where the application of PS on the soil surface increased the available soil $\mathrm{P}$ up to $0.15 \mathrm{~m}$ depth. The levels of $\mathrm{K}$ were also higher in the areas with the use of manure, being higher in the area with longer use, which was already expected, due to this being a residue rich in this element, providing accumulation in the soil in the short term (KRAJESKI; POVALUK, 2014).

The behavior of $\mathrm{S}$ was similar to $\mathrm{K}$, presenting higher contents in A14, A2 and NF, respectively, according to the time of use of PS in the soil, as well as due to the microbial and organic activity of these areas, provided by the organic fertilization (KRAJESKI; POVALUK, 2014). The potential acidity $(\mathrm{H}+\mathrm{Al})$ and the potential cation exchange capacity $\left(\mathrm{CTC}_{\mathrm{pH} 7}\right)$ were similar between the analyzed areas, as well as the aluminum (Al) and saturated $\mathrm{Al}$ content, and the latter attributes were not verified in soil analyses.

Some physical properties such as texture, distribution, pore diameter and soil structure can serve directly as indicators of SQ, as they are directly linked to the variation and the amount of water that the soil can store (ORTIZ et al., 2017), being fundamental to be studied for the understanding of the physical quality of the soil in the context of the SQ as a whole. Regarding the clay content, area A14 presented a higher value than area NF, which did not differ from A2 (Table 2). Several indicators of SQ can be modified or improved, in 
contrast to others that are permanent properties, as is the case of texture, being very little modified with time and management (ALVARES et al., 2011), being an intrinsic characteristic of the type of soil, being subject among other aspects, to spatial variability.

Table 2. Physical attributes of soil in the area of native forest (NF), ryegrass + tifton pasture, using pig slurry for 14 years (A14) and 2 years (A2).

\begin{tabular}{|c|c|c|c|c|c|c|c|c|c|}
\hline \multirow{3}{*}{ Area } & \multicolumn{9}{|c|}{ Soil physical attributes } \\
\hline & \multirow{2}{*}{\multicolumn{2}{|c|}{$\frac{\text { Clay }}{\mathrm{g} \mathrm{kg}^{-1}}$}} & \multirow{2}{*}{\multicolumn{2}{|c|}{$\frac{\mathrm{Ds}^{1}}{\mathrm{~g} \mathrm{~cm}^{-3}}$}} & $\mathrm{Pt}^{2}$ & $\mathrm{Mac}^{3}$ & & $\mathrm{Mic}^{4}$ & \\
\hline & & & & & \multicolumn{5}{|c|}{ - } \\
\hline $\mathrm{NF}$ & 17.7 & $\mathrm{~b}^{*}$ & 0.81 & $\mathrm{~b}$ & $0.64^{\mathrm{ns}}$ & 0.33 & $\mathrm{a}$ & 0.31 & $\mathrm{~b}$ \\
\hline A14 & 28.3 & $\mathrm{a}$ & 1.29 & $\mathrm{a}$ & 0.59 & 0.17 & $\mathrm{~b}$ & 0.42 & $\mathrm{a}$ \\
\hline $\mathrm{A} 2$ & 22.3 & $\mathrm{ab}$ & 1.23 & $\mathrm{a}$ & 0.63 & 0.19 & $\mathrm{~b}$ & 0.43 & $\mathrm{a}$ \\
\hline
\end{tabular}

${ }^{1} \mathrm{Ds}=$ soil density; ${ }^{2} \mathrm{Pt}=$ Total porosity; ${ }^{3} \mathrm{Mac}=$ macroporosity $;{ }^{4} \mathrm{Mic}=$ microporosity. *Means followed by the same letter in the column do not differ from each other by Tukey's $(\mathrm{p} \leq 0.05)$, and $\left({ }^{\mathrm{ns}}\right)$ not significant.

Soil density (Ds) is directly related to soil porosity, and in soils with advanced compaction degree, aeration becomes deficient in high water content, and resistance to penetration increases (LAPEN et al., 2004), in addition to reducing the content of water potentially available to plants (LIMA et al., 2009). Ds is naturally smaller in native forests (SILVA et al., 2015), as observed in the present study, and because it is a factor that directly alters the distribution of macropores (Mac) and Micropores (Mic), one can notice an increase in Ds and Mic, besides the decrease of Mac due to replacement of the original forest cover in A14 and A2 (Table 2).

Structural changes resulting from improper management also alter pore size and continuity distribution (OLIVEIRA et al., 2004) and consequently modify soil water dynamics related to groundwater infiltration and recharge (LIMA et al., 2009). The fact that there was bovine trampling in the pasture areas also contributed to a higher decrease in soil density and macroporosity, causing compaction in the $0-0.10 \mathrm{~m}$ layer (LANZANOVA et al., 2007), as observed in Table 2. Both density and macroporosity can significantly influence root growth and crop yield (SILVA et al., 2000), highlighting the importance of these parameters for studies involving soil quality.

The results showed that the use of PS, as well as the time of use in areas A14 and A2, provided an increase in the abundance of nematodes in relation to $\mathrm{NF}$, however, a reduction in species richness was also observed due to the substitution of forest cover (Table 3).

Table 3. Mean abundance of the nematofauna taxonomic groups $\left(100 \mathrm{~cm}^{3}\right.$ of soil), richness of individuals per treatment, and Shannon diversity index (H), Pielou uniformity (J) and Simpson dominance (Is) in the native forest area (NF), ryegrass pasture + tifton, using pig slurry for 14 years (A14) and 2 years (A2).

\begin{tabular}{|c|c|c|c|c|c|c|}
\hline \multirow[t]{2}{*}{ Taxonomic group } & \multicolumn{6}{|c|}{ Area } \\
\hline & \multicolumn{2}{|c|}{ NF } & \multicolumn{2}{|c|}{$\mathrm{A} 14$} & \multicolumn{2}{|c|}{ A2 } \\
\hline Discocriconemella & 11.1 & $\mathrm{a}^{*}$ & 0.0 & $\mathrm{~b}$ & 0.0 & $\mathrm{~b}$ \\
\hline Helicotylenchus & 10.0 & $\mathrm{~b}$ & 246.7 & $a b$ & 286.7 & $\mathrm{a}$ \\
\hline Meloidogyne & 7.8 & ns & 66.7 & & 57.8 & \\
\hline Paratylenchus & 7.8 & $\mathrm{a}$ & 0.0 & $\mathrm{~b}$ & 0.0 & b \\
\hline Pratylenchus & 12.2 & $\mathrm{~b}$ & 714.4 & $\mathrm{a}$ & 544.4 & $\mathrm{a}$ \\
\hline Trichodorus & 2.2 & $\mathrm{a}$ & 0.0 & $\mathrm{~b}$ & 0.0 & $\mathrm{~b}$ \\
\hline Tylenchus & 1.1 & $\mathrm{a}$ & 0.0 & $\mathrm{~b}$ & 0.0 & $\mathrm{~b}$ \\
\hline Xiphinema & 5.6 & ns & 25.6 & & 0.0 & \\
\hline Free living & 95.6 & $\mathrm{c}$ & 1341.1 & $\mathrm{a}$ & 694.4 & b \\
\hline Abundance & 153.3 & $\mathrm{c}$ & 2394.4 & $\bar{a}$ & 1583.3 & $\mathrm{~b}$ \\
\hline Total richness & 9 & $\mathrm{a}$ & 5 & $\mathrm{~b}$ & 4 & $\mathrm{~b}$ \\
\hline $\mathrm{H}$ & 1.38 & $\mathrm{a}$ & 1.07 & $\mathrm{~b}$ & 1.16 & $a b$ \\
\hline $\mathrm{J}$ & 0.63 & $\mathrm{~b}$ & 0.66 & $\mathrm{~b}$ & 0.84 & $\mathrm{a}$ \\
\hline Is & 0.41 & ns & 0.41 & & 0.34 & \\
\hline
\end{tabular}

*Means followed by the same letter in the line do not differ from each other by Tukey's ( $\mathrm{p} \leq 0.05$ ), and (ns) not significant.

Much of the abundance value is due to the increase in the proportion of phytonematodes in relation to free-living nematodes in the pasture areas, this being $44.0 \%, \quad 56.1 \%$ and $37.7 \%$ of phytonematodes in the areas A14, A2 and NF, respectively. Therefore, this increase in abundance is 
caused by the removal of forest cover, detrimental to these areas and the introduction of pasture (Table 3 ). This increase in phytonematode abundance, as well as in its representativeness, and decrease in the richness of collected genera is mainly due to the decrease in the diversity of available foods (ARIEIRA et al., 2016), since in A14 and A2 there is only ryegrass and tifton pasture, causing a lower diversity of nematodes, increasing the dominance of phytonematodes in relation to other groups, influencing the entire food chain and causing imbalance between populations (Table 3 ).

However, the greater abundance in area A14 in relation to area A2 can be attributed to the successive use of PS, which contributed to the improvement of soil quality after 14 years of application, being validated by the higher number of free-living nematodes in area A14 compared to area A2. Free-living nematodes, in turn, can be considered among the most important bioindicators, contributing to the decomposition rates of organic matter and influencing the processes of nutrient cycling (GOULART, 2009), attributing these environments a greater resilience. In addition, freeliving nematodes act in the degradation of organic materials, prey on bacteria, fungi, mites and even other nematodes such as phytophages, and these may be related to the ecological condition of the soil (XU; MAGE, 2001), they can be used as bioindicators in evaluation of the impact of human activities that cause environmental changes, as well as in the evaluation of productive sustainability (GOULART, 2009). Thus, it is possible to infer that the successive use of PS for 14 years in ryegrass + tifton pasture area (A14) contributed to the increase in the number of free-living nematodes in the edaphic environment, in relation to the area with the use of PS for 2 years (A2) and the area of NF, which may, among other aspects, be associated with the increase in soil OM content with the successive use of PS (Table 1).

To understand the processes that occur in the soil, due to the use and management adopted, the structuring of the food web is a complete tool that can help to identify the soil ecosystem, and information such as density, diversity indices, species richness, soil structure and presence of freeliving nematodes, as well as phytonematodes, which may vary over time due to these factors (RITZINGER et al., 2010).

The use of indexes is widely adopted for a better classification of environmental biodiversity, contributing to a better interpretation when there is a set of data that make the results not easily visible. The NF area presented the highest diversity, with total richness of nine distinct groups of collected nematodes, besides having a higher diversity index $(\mathrm{H})$, in relation to the A14 area, without significantly differing from area A2 (Table 3 ). The increase in the diversity of fauna and the reestablishment of the food chain can be indicative that the ecosystem has been maintaining equilibrium and becoming more sustainable. The impacts of changes in diversity depend on ecosystem biological conditions, for example, the richness and density of soil fauna species prior to interference and the intensity of the disturbance imposed on the native ecosystem (SILVA et al., 2013), these parameters may serve as important indicative references in the analysis of SQ attributes.

The most uniform treatment was A2 according to the equitability index $(\mathrm{J})$, and this treatment also had the $\mathrm{H}$ index similar to treatment $\mathrm{NF}$ and A14. However, A2 presented lower richness of nematofauna groups (Helicotylenchus, Meloidogyne, Pratylenchus and free-living nematodes), compared to NF, without differing from A14. In addition, area A2 showed about half of the free-living nematode specimens in relation to treatment A14, which also occurred in a smaller amount in native environment (NF) due to ecological balance, but maintaining a higher relative occurrence than in other environments. The $\mathrm{H}$ and $\mathrm{J}$ indices should be considered jointly with the soil physical and chemical indicators to determine the quality of the edaphic environment.

The fact that the richness was lower in A2 compared to A14 is due to the presence of phytonematodes of the genus Xiphinema (MONDINO et al., 2009) in the second area, probably due to a longer food restriction than in A2, and even because of the better soil conditions provided by PS (BARETTA et al., 2007) for a considerably longer time. The dominance index was relatively stable among the analyzed treatments, and no significant difference was detected.

The genus Discocriconemella has been associated with native environments, allowing the differentiation of native vegetation communities from intensive cropping systems (CARVALHO et al., 2011). The same was observed by Goulart (2009), where the occurrence of Discocriconemella in native cerrado served to distinguish this area from the others. Thus, it can be concluded that the occurrence of this genus is capable of differentiating areas without significant anthropic interference, such as native forests and fields from intensively cultivated agricultural areas, where there is a lower SQ. The genera Paratylenchus, Trichodorus and Tylenchus had behavior similar to the last one, occurring only in NF (Table 3). Based on this, it can be concluded that the occurrence of these nematofauna groups are potential indicators of environmental and SQ changes (GOULART, 2009) in environments with substitution of native vegetation cover and use of PS.

The genus Pratylenchus occurred in all 
treatments, but with significantly greater abundance in pasture areas with longer use of PS, that is in the A14 treatment. This genus is polyphagous and is present in the main areas of agricultural cultivation (INOMOTO et al., 2011), allowing the discrimination between distinct treatments (GOULART, 2009), being a great indicator of food restriction as in the case of monocultures.

The variables were divided into two main components that explained $82.43 \%$ of the variance (Table 4). The first component explained $57.29 \%$ of the total variance, consisting of $\mathrm{Mac}, \mathrm{pH}, \mathrm{V}$, effective CTC and pH7, Discocrinemella, Paratylenchus, Trichodorus and Tylenchus, in addition to presenting a strong negative relation for Ds, being visibly important to differentiate the areas considered in the study, mainly native vegetation (NF) from pasture areas using PS (A14 and A2), as the four genera of newly cited nematodes (with positive relation), as previously seen, only occurred in a native environment (Table 3 ).

Table 4. Principal component analysis of the indicators of the chemical, physical and biological quality of the soil in the area of native forest (NF), ryegrass + tifton pasture, using pig slurry for 14 years (A14) and 2 years (A2).

\begin{tabular}{lcc}
\hline \multirow{2}{*}{ Variance component } & \multicolumn{2}{c}{ Principal component } \\
\cline { 2 - 3 } Eigen values & 13.48 & 2 \\
\% of variance explained & 57.29 & 25.14 \\
\% of accumulated variance & 57.29 & 82.43 \\
\hline Quality indicator & \multicolumn{2}{c}{ Correlation matrix } \\
\hline Clay (Arg) & -0.769 & 0.092 \\
Soil density (Ds) & -0.988 & -0.095 \\
Total porosity (Pt) & 0.477 & -0.095 \\
Macroporosity (Mac) & 0.918 & 0.141 \\
Microporosity (Mic) & -0.970 & 0.038 \\
pH H & -0.015 \\
Ca & 0.953 & 0.287 \\
Mg & 0.527 & -0.489 \\
CTC pH7 $_{\text {CTC }}$ effective & -0.422 & 0.141 \\
Base saturation (V) & 0.930 & 0.062 \\
Organic material (OM) & 0.994 & -0.129 \\
P & 0.967 & 0.871 \\
K & 0.458 & 0.800 \\
S & -0.352 & 0.578 \\
Discocrinemella (DIS) & -0.655 & -0.158 \\
Helicotylenchus (HEL) & 0.739 & 0.101 \\
Meloidogyne (MEL) & 0.987 & -0.688 \\
Paratylenchus (PAR) & -0.085 & 0.721 \\
Pratylenchus (PRA) & -0.085 & 0.103 \\
Trichodorus (TRI) & 0.988 & 0.281 \\
Tylenchus (TYL) & -0.208 & 0.099 \\
Xiphinema (XIP) & 0.977 & 0.104 \\
Free living (VL) & 0.989 & -0.970 \\
\hline & 0.680 & 0.841 \\
\hline Valis & -0.131 & \\
\hline
\end{tabular}

*Values highlighted in bold / italic present a factorial load $>0.700$ for the respective principal component.

As for the physical attributes, according to the means test already reported (Table 2), Mac and Ds were statistically different between $\mathrm{NF}$ and the pasture areas using PS (A14 and A2), which can be reviewed in the graphical representation of PCA (Figure 1). Effective CTC, V\%, and CTCpH7 were lower in pasture areas, showing a high relationship with these areas. 


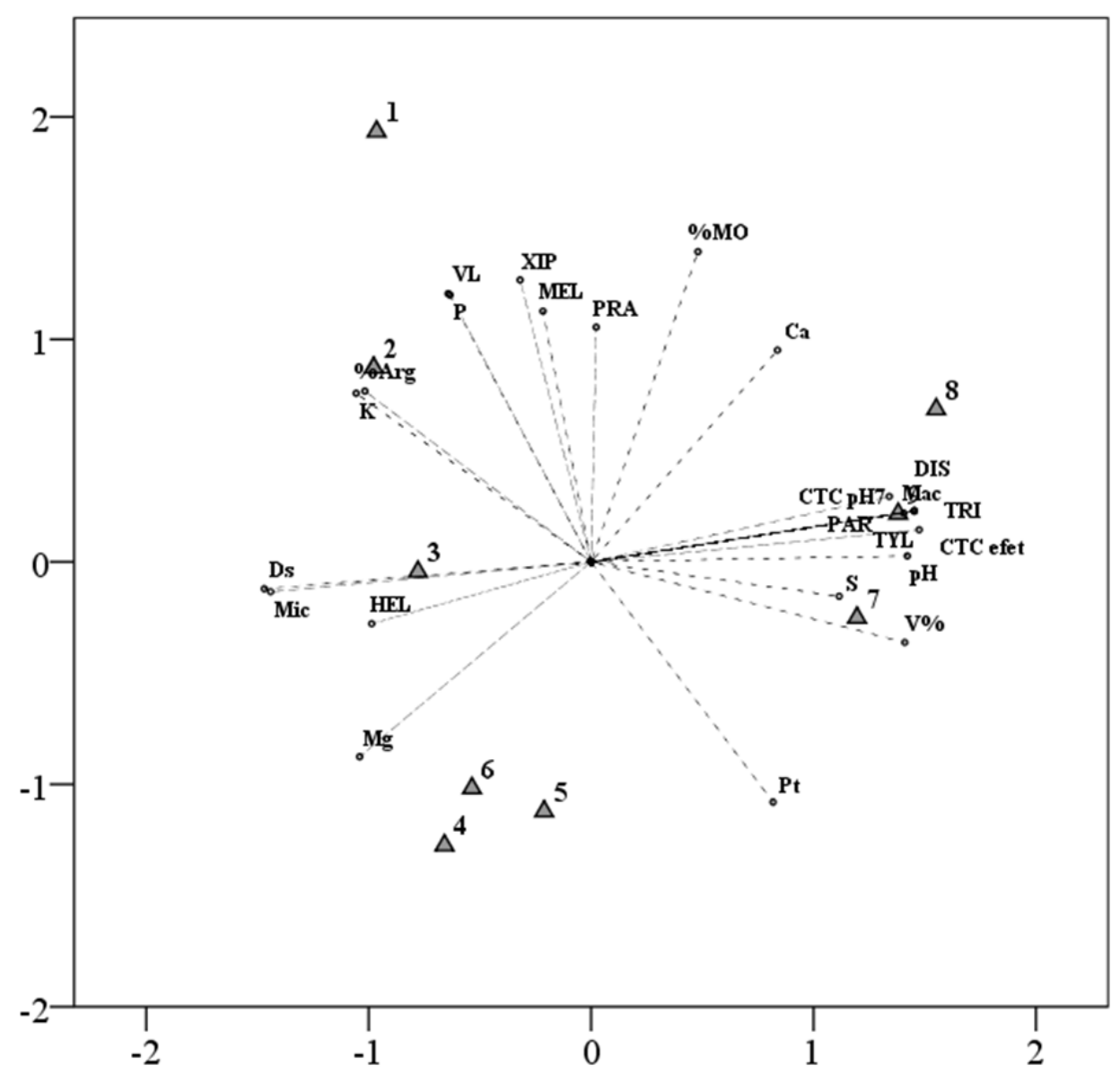

Figure 1. Graphical representation of Principal Component Analysis (PCA) of the native forest area and pasture areas with successive use of PS for 14 and 2 years, and the physical, chemical and biological attributes of the soil. 1, 2 and 3: Blocks in the field of NF treatment; 4, 5 and 6: A14 treatment blocks; 7, 8 and 9 (point 9 is under the Mac attribute): field blocks of A2 treatment; \% Arg: percentage of clay; \%MO: Percentage of organic matter; V\%: base saturation; CTCefet: Effective CTC; DIS: Discocriconemella; HEL: Helicotylenchus; MEL: Meloidogyne; PAR: Paratylenchus; PRA: Pratylenchus; TRI: Trichodorus; TIL: Tylenchus; XIP: Xiphinema; VL: Free-living nematodes.

The second component, in turn, explained $25.14 \%$ of the total variance, and was composed of the chemical attributes $\mathrm{OM}$ and $\mathrm{P}$, and the biological Xiphinema, Meloidogyne and free-living nematodes. The levels of OM and the occurrence of Xiphinema were higher in NF and A14 compared to A2, showing affinity to these areas. The $\mathrm{P}$ contents and the occurrence of Meloidogyne and free-living nematodes were much higher in A14 and A2 in relation to the native environment (NF), presenting a strong negative affinity to the latter area, serving to differentiate them regarding the edaphic quality. In general terms, based on the analysis of the results obtained, it is possible to infer that the successive use of PS causes changes in some chemical and physical attributes of the soil, in addition to favoring the free-living nematofauna of the soil.

\section{CONCLUSION}

The use of pig slurry (PS) in ryegrass + tifton pasture areas increases soil $\mathrm{P}$ content compared to the native forest area (NF), and the successive application for 14 years results in soil organic matter (OM) content similar to that found in the NF area.

The soil physical attributes, density and microporosity, increase with the successive application of PS in ryegrass + tifton pasture areas, while macroporosity decreases compared to NF areas.

The successive use of PS for 14 years in an area with ryegrass + tifton pasture (A14) contributes to the increase in the number of free-living nematodes in the edaphic environment, in relation to the area with the use of PS for 2 years (A2) and the NF area.

Nematodes of the Discocriconemella, Paratylenchus, Pratylenchus, Trichodorus, Tylenchuse and free-living groups were efficient as indicators of soil quality, since they were able to show evidences of alterations in the chemical and physical attributes of the soil between ryegrass + tifton pasture areas with successive use of PS and in 
relation to the native forest.

\section{REFERENCES}

ALVARES, C. A. et al. Spatial variability of physical and chemical attributes of some forest soils in southeastern of Brazil. Scientia Agricola, v. 68, n. 6, p. 697-705, 2011.

ARIEIRA, G. O. et al. Depth-stratified soil sampling for assessing nematode communities. Semina. Ciências Agrárias, v. 37, n. 2, p. 715-728, 2016.

BARETTA, D. et al. Earthworm populations samples using collection methods in Atlantic Forests with Araucaria angustifolia. Scientia Agricola, v. 64, n. 4, p. 384-392, 2007.

BERWANGER, A. L. et al. Alterações no teor de fósforo no solo com aplicações de dejetos líquidos de suínos. Revista Brasileira de Ciência do Solo, v. 32, n. 6, p. 2525-2532, 2008.

BISON-PINTO, M. A. et al. Aplicação de dejeto líquido de suínos e manejo do solo na sucessão aveia/milho. Pesquisa Agropecuária Tropical, v. 44, n. 2, p. 205-212, 2014.

CARVALHO, J. P. et al. Diversidade de fitonematoides em áreas nativas e de agricultura no cerrado baiano. Magistra, v. 23, n. 1, p. 262-267, 2011.

CARVALHO, R. et al. Atributos da qualidade de um solo sob sistema agroflorestal. Pesquisa Agropecuária Brasileira, v. 39, n. 11, p. 11531155, 2004.

COMISSÃO DE QUÍMICA E FERTILIDADE DO SOLO - CQFS RS/SC. Manual de adubação e de calagem para os estados do Rio Grande do Sul e de Santa Catarina. 11. ed. Porto Alegre, RS: Sociedade Brasileira de Ciência do Solo, Núcleo Regional Sul, 2016. 376 p.

FREITAS, D. A. F. et al. Índices de qualidade do solo sob diferentes sistemas de uso e manejo florestal e cerrado nativo adjacente. Revista Ciência Agronômica, v. 43, n. 3, p. 417-428, 2012.

GOMILDE, P. H. O. et al. Atributos físicos, químicos e biológicos do solo em ambientes de voçorocas no município de Lavras - MG. Revista Brasileira de Ciência do Solo, v. 35, n. 2, p. 567577, 2011.

GOULART, A. M. C. Análise de dados em estudos de diversidade de nematoides. 1. ed. Planaltina, DF: Embrapa Cerrados, 2009. 46 p. (Embrapa
Cerrados, Documentos 251)

HOCEINI, F. et al. Effect of the edaphic environment on the diversity and trophical structure of the nematodes of algerian viticultural soils. Advances in Environmental Biology, v. 11, n. 2, p. 27-33, 2017.

INOMOTO, M. M. et al. Sucessão de cultura sob pivô central para controle de fitonematoides: variação populacional, patogenicidade e estimativa de perdas. Tropical Plant Pathology, v. 36, n. 3, p. 178-185, 2011.

INSTITUTO BRASILEIRO DE GEOGRAFIA E ESTATÍSTICA - IBGE. Manual técnico da vegetação brasileira. 2. ed. Rio de Janeiro, RJ: IBGE, 2012. 271 p. (Série Manuais Técnicos em Geociências).

JENKINS, W. R. A rapid centrifugal-flotation technique for separating nematodes from soil. Plant Disease Reporter, v. 48, n. 9, p. 692, 1964.

KRAJESKI, R.; POVALUK, M. Alterações no solo ocasionadas pela fertirrigação dos dejetos suínos. Saúde e Meio Ambiente, v. 3, n. 1, p. 3-18, 2014.

LANZANOVA, M. E. et al. Atributos físicos do solo em sistema de Integração Lavoura-Pecuária sob Plantio Direto. Revista Brasileira de Ciência do Solo, v. 31, n. 5, p. 1131-1140, 2007.

LAPEN, D. R. et al. Least limiting water range indicators of soil quality and corn production, eastern Ontario, Canada. Soil and Tillage Research, v. 78, n. 2, p. 151-170, 2004.

LIMA, V. M. P. et al. Intervalo hídrico ótimo e porosidade de solos cultivados em área de proteção ambiental do Sul de Minas Gerais. Revista Brasileira de Ciência do Solo, v. 33, n. 10, p. 1087 1095, 2009.

MALUF, J. R. T. Nova classificação climática do Estado do Rio Grande do Sul. Revista Brasileira de Agrometeorologia, v. 8, n. 1, p. 141-150, 2000.

MOÇO, M. K. S. et al. Caracterização da fauna edáfica em diferentes coberturas vegetais na região Norte Fluminense. Revista Brasileira de Ciência do Solo, v. 29, n. 4, p. 555-564, 2005.

MONDINO, E. A. et al. Avaliação das comunidades de nematoides do solo em agroecossistemas orgânicos. Acta Scientiarum. Agronomy, v. 31, n. 3, p. 509-515, 2009.

MORAIS, E. R. C. et al. Indicadores da qualidade química do solo em áreas cultivadas com mamoeiro 
irrigado. Revista Brasileira de Engenharia Agrícola e Ambiental, v. 19, n. 6, p. 587-591, 2015.

OLIVEIRA, G. C. et al. Caracterização química e físico-hídrica de um Latossolo Vermelho após 20 anos de manejo e cultivo do solo. Revista Brasileira de Ciência do Solo, v. 28, n. 2, p. 335-344, 2004.

ORTIZ, P. F. S. et al. Physical qualities of an Ultisol under sugarcane and Atlantic forest in Brazil. Geoderma Regional, v. 11, n. 12, p. 62-70, 2017.

PEREIRA, M. P. S. et al. Fauna de formigas como ferramenta para monitoramento de área de mineração reabilitada na Ilha da Madeira, Itaguaí, RJ. Ciência Florestal, v. 17, n. 3, p. 197-204, 2007.

RESENDE, T. M. et al. Avaliação física do solo em áreas sob diferentes usos com adição de dejetos animais no bioma Cerrado. Bioscience Journal, v. 28, n. 1, p. 179-184, 2012.

RITZINGER, C. H. S. P. et al. Nematoides: bioindicadores de sustentabilidade e mudanças edafoclimáticas. Revista Brasileira de Fruticultura, v. 32, n. 4, p. 1289-1292, 2010.

ROVEDDER, A. P. M. et al. Compreensão e aplicabilidade do conceito de solo florestal. Ciência Florestal, v. 23, n. 3, p. 517-528, 2013.

SANTORUFO, L. et al. Soil invertebrates as bioindicators of urban soil quality. Environmental Pollution, v. 161, n. 2, p. 57-63, 2012.

SANTOS, G. G. et al. Macrofauna edáfica associada a plantas de cobertura em plantio direto em um Latossolo Vermelho do Cerrado. Pesquisa Agropecuária Brasileira, v. 43, n. 1, p. 115-122, 2008.

SCHERER, E. E. et al. Atributos químicos do solo influenciados por sucessivas aplicações de dejetos suínos em áreas agrícolas de Santa Catarina. Revista Brasileira de Ciência do Solo, v. 34, n. 4, p. 1375 1383, 2010.

SCIPIONI, M. C. et al. Fitossociologia em fragmento florestal no noroeste do estado do Rio Grande do Sul. Ciência Florestal, v. 21, n. 3, p. 409419, 2011.

SILVA JUNIOR, C. A. et al. A. Atributos químicos do solo sob conversão de floresta amazônica para diferentes sistemas na região norte do Pará, Brasil. Bioscience Journal, v. 28, n. 4, p. 566-572, 2012. on the diversity and activity of soil biota in pasture areas. Ciência Rural, v. 46, n. 10, p. 1756-1763, 2016.

SILVA, D. M. et al. Indicadores microbiológicos de solo em pastagem com aplicação sucessiva de dejetos e suínos. Revista Brasileira de Ciência do Solo, v. 39, n. 6, p. 1585-1594, 2015.

SILVA, R. F. et al. Doses de dejeto líquido de suínos na comunidade da fauna edáfica em sistema plantio direto e cultivo mínimo. Ciência Florestal, v. 44, n. 3, p. 418-424, 2014.

SILVA, R. F. et al. Fauna edáfica influenciada pelo uso de culturas e consórcios de cobertura do solo. Pesquisa Agropecuária Tropical, v. 43, n. 2, p. 130 $-137,2013$.

SILVA, V. R. et al. Densidade do solo, atributos químicos e sistema radicular do milho afetados pelo pastejo e manejo do solo. Revista Brasileira de Ciência do Solo, v. 24, n. 1, p. 191-199, 2000.

TEDESCO, M. J. et al. Análise de solo, plantas e outros materiais. $2^{\mathrm{a}}$ ed. Porto Alegre, RS: Departamento de solos da UFRGS, 1995. 174 p.

TEIXEIRA, P. C. et al. Manual de Métodos de Análise de Solo. 3. ed. Brasília, DF: Embrapa, 2017. $573 \mathrm{p}$.

URAMOTO, $K$. et al. Análise quantitativa e distribuição de populações de Anastrepha (Diptera: Tephritidae) no campus Luiz de Queiroz. Neotropical Entomology, v. 34, n. 1, p. 33-39, 2005

XU, W.; MAGE, J. A. A review of concepts and criteria for assessing agroecosystem health including a preliminary case study of southern Ontario. Agriculture, Ecosystems \& Environment, v. 83, n. 3 , p. 215-233, 2001

SILVA, D. M. et al. Effects of pig slurry application 